\title{
ADENOSINE-TO-INOSINE RNA EDITING MAY BE IMPLICATED IN HUMAN PATHOGENESIS
}

Kliuchnikova AA $\bowtie$, Moshkovskii SA

Institute of Biomedical Chemistry, Moscow, Russia

Pirogov Russian National Research Medical University, Moscow, Russia

Adenosine-to-inosine (A-to-I) RNA editing is a common mechanism of post-transcriptional modification in many metazoans including vertebrates; the process is catalyzed by adenosine deaminases acting on RNA (ADARs). Using high-throughput sequencing technologies resulted in finding thousands of RNA editing sites throughout the human transcriptome however, their functions are still poorly understood. The aim of this brief review is to draw attention of clinicians and biomedical researchers to ADAR-mediated RNA editing phenomenon and its possible implication in development of neuropathologies, antiviral immune responses and cancer.

Keywords: RNA-specific adenosine deaminase (ADAR), RNA editing, immune resistance, malignant tumour, neurodegenerative disease

Funding: the work was performed within The Programme for fundamental scientific research of state science academies for $2013-2020$.

Author contribution: both authors have contributed equally to manuscript writing

$\triangle$ Correspondence should be addressed: Anna A. Kliuchnikova

Pogodinskaya 10, bld. 8, Moscow, 119121; a.kliuchnikova@gmail.com

Received: 13.08.2018 Accepted: 06.04.2019 Published online: 16.04.2019

DOI: $10.24075 / \mathrm{brsmu} .2019 .028$

\section{ПРИРОДНОЕ РЕДАКТИРОВАНИЕ РНК С ЗАМЕНОЙ АДЕНОЗИНА НА ИНОЗИН МОЖЕТ УЧАСТВОВАТЬ В ПАТОГЕНЕЗЕ БОЛЕЗНЕЙ ЧЕЛОВЕКА}

\section{А. А. Ключникова $џ$, С. А. Мошковский}

Научно-исследовательский институт биомедицинской химии имени В. Н. Ореховича, Москва, Россия

Российский национальный исследовательский медицинский университет имени Н. И. Пирогова, Москва, Россия

\begin{abstract}
Редактирование РНК с заменой аденина на инозин является наиболее распространенным природным механизмом посттранскрипционной модификации у разных многоклеточных организмов, включая позвоночных, и катализируется ферментами семейства PHK-зависимых аденозиндезаминаз ADAR. Недавние исследования с использованием высокопроизводительного секвенирования нуклеиновых кислот позволили выявить тысячи участков такого редактирования и у человека, однако функция многих из них остается не до конца ясной. Мы хотим привлечь внимание клиницистов и специалистов по биомедицине к ADAR-опосредованному редактированию мРНК и его возможному участию в развитии болезней нервной системы, противовирусных иммунных реакций и злокачественных опухолей.
\end{abstract}

Ключевые слова: РНК-зависимая аденозиндезаминаза (ADAR), редактирование PHK, иммунитет, злокачественная опухоль, нейродегенеративные заболевания

Финансирование: работа выполнена в рамках Программы фундаментальных научных исследований государственных академий наук на $2013-2020$ гг. Информация о вкладе авторов: оба автора в равной степени участвовали в написании текста статьи.

$\searrow$ Для корреспонденции: Анна Алексеевна Ключникова ул. Погодинская, д. 10, стр. 8, г. Москва, 119121; a.kliuchnikova@gmail.com

Статья получена: 13.08.2018 Статья принята к печати: 06.04.2019 Опубликована онлайн: 16.04.2019

DOI: $10.24075 /$ vrgmu.2019.028

RNA editing is one of mechanisms of post-transcriptional modification of nucleotide chemical structure. Here we review RNA editing as a natural phenomenon distinguished from programmable genome editing tools such as RNA editing with CRISPR-Cas systems in bacteria. The most common type of natural RNA editing is adenosine to inosine (A-to-I) deamination catalyzed by RNA-specific adenosine deaminases (ADARs). The process is called "editing" as such modifications in many cases lead to changing the informational content of the RNA.

In humans, three genes encoding ADAR proteins are found; ADAR1 (encoded by adar gene) and ADAR2 (encoded by adarb1 gene) proteins have enzymatic activity while ADAR3 (encoded by adarb2) acts as an inhibitor of editing [1]. Active ADAR enzymes are binding to dsRNA and converting adenosine (A) to inosine (I) by deamination. Codon changes can arise from such editing. Deamination in coding regions of RNA may result in recoding of proteins as inosine typically mimicks guanosine during translation [2].
ADAR-mediated RNA editing was unknown till 1987; recently, the process was shown to be widespread in genomes of most animals and associated with different functions. Thus, RNA editing was reported to be particularly common in some Protostomia - cephalopods, in particular - as compared to other invertebrates and was supposed to sustain molecular plasticity under changing environmental conditions and the evolutionary conservatism at the same time [3].

In mammals, RNA editing occurs as well. In a recent largescale transcriptome research, the process was investigated comprehensively and more than 20,000 editing sites in human and mouse were identified. More than two thousand human editing sites were reported to lead to amino acid substitutions in the encoded proteins [1]. A variety of transcriptome editing sites is called "RNA editome" similarly to other molecular "-omes".

Until recently, RNA editing role was unclear. However, using knockout rodent models allowed to demonstrate that ADAR1 was mainly associated with control of innate immune responses 
while ADAR2 regulated signal transmission and excitability in the central nervous system [4]. ADARs edit various substrates including matrix RNA, short and long non-coding RNA as well as viral RNA, that have only one thing in common: double stranded RNA. The scale of the phenomenon was estimated only recently, and due to its complexity the data on RNA editing functions in different objects are accumulated slowly.

Let us consider the significance of phenomenon of natural editing RNA observed at the proteome level in humans and laboratory animals as a process possibly contributing to development of antiviral immune responses, nervous system diseases and cancer.

\section{RNA editing in the central nervous system}

RNA editing occurs actively in the central nervous system (CNS). It is associated mainly with ADAR2 enzyme [1]. Such editing is known to make point substitutions in related sequences of voltage-gated ion channels and $G$ protein-coupled receptors of the nervous system. RNA editing events in GluK and GluA glutamate receptors are well studied. Normally, RNA editing results in an amino acid substitution of glutamine for arginine in one of the glutamate receptor subunits during development of the nervous system. The receptors containing the edited subunit become $\mathrm{Ca}^{2+}$-impermeable while channels containing unedited subunits are $\mathrm{Ca}^{+}-$permeable. Neurons with such subunits are subject to a "physiological" excitotoxicity due to an increase of glutamate content in synapses. It is known to result in neuronal death and be an important factor of development of some neurodegenerative disorders, a spinal neurodegeneration at amyotrophic lateral sclerosis (ALS), in particular [5]. Mutations in adarb1 could contribute to epilepsy and diseases involving neuronal plasticity defects such as autism and Martin-Bell syndrome [4]. In mice, the ADAR2 knockout resulting in appearance of unedited glutamate receptors is lethal as it causes overexcitement in brain cells with strong epileptic seizures.

\section{RNA editing and virus-induced immunity}

Some findings point to ADAR1 implication in immunity including immune responses to infection with RNA viruses. It was shown that ADAR1 enzyme can play a role in mechanisms of protection against viral infections and inflammation. Thus, ADAR1 can edit the hepatitis $C$ virus RNA limiting its replication [6]. The adenosinedeaminase was shown to edit influenza virus to a greater extent compared to measles virus - on the one hand, this can make influenza virus nonfunctional, while on the other hand, can promote mutagenesis and evasion from immunity [7].

Type I interferon is known to induce ADAR1 increasing synthesis of its long p150 form however, such activity interferes with formation of stress granules against measles virus. Thus, ADAR1 is considered to be a suppressor of innate immune responses in this case [8].

Missens mutations leading to amino acid substitutions in ADAR1 reduce activity of RNA editing and cause AicardiGoutières syndrome (AGS). AGS is characterized by progressing encephalopathy and interferonopathy mimicking a viral infection [9] that demonstrates the involvement of ADAR1 into immune response.

\section{RNA editing and cancer}

The results of the recent research performed within The Cancer Genome Atlas (TCGA) project facilitated systematization of data on genomes and transcriptomes in different tumor types [10]. The use of available sequencing data made it possible to obtain RNA editing libraries. Significant RNA editing differences have been observed between cancerous and normal tissues. For most of the tested cancer types including head and neck cancer, breast cancer and thyroid carcinoma, the increased RNA editing levels were reported that was associated with high ADAR1 expression levels in tumors [11].

Occurrence of RNA editing events in brain cells becomes higher with age however, may decrease in glioblastoma [12]. Similar to cancer driver somatic mutations, RNA editing events can promote tumor progression. Thus, both in vitro and in vivo experiments provided data on a protein playing an important role in cell growth and proliferation due to maintaining the homeostasis of polyamine in cells. RNA editing of AZIN1 (encoding antizyme inhibitor 1 ) by ADAR1 results in a serine-toglycine substitution at residue 367 of AZIN1. The edited form has a stronger affinity to antizyme and induces a cytoplasmicto-nuclear AZIN1 translocation resulting in a more aggressive behavior of tumor [13]. Thus, the edited protein can be considered a potential therapeutic target.

Some RNA editing events can be used as predictive markers and have an effect on tissue response in cancer therapy. For example, a glycine-to-arginine substitution at position 764 (R764G) in glutamate receptor GRIA2 and an isoleucine to valine substitution (1635V) at COG3 protein responsible for vesicle-mediated transport between the Golgi complex and endoplasmic reticulum, increase sensitivity of mitogen-activated protein kinase kinase (MAPKK) to kinase inhibitors [14]. ADAR2 onco-supressing properties are of particular interest in studying glioblastoma. ADAR2-mediated editing the CDC14B phosphatase responsible for DNA damage can modulate a cell cycle pathway involving the Skp2/p21/p27 proteins and inhibit growth of glioblastoma [12].

Although a large amount of information on ADARs and RNA editing has been already accumulated, the biological significance of RNA editing remains largely unknown. In most cases it is not clear whether the editing events are implicated in transcriptome regulation or provide proteome functional plasticity or perhaps related to molecular noise. ADARs are known to edit a variety of dsRNA substrates such as matrix RNA, short and long non-coding RNA as well as viral RNA. The scale of this phenomenon becomes recently clear with a progress in studying RNA modifications at a genomewide scale [1] that however require further functional confirmation.

Thus, ADAR1 activity is known to be connected with antiviral immune responses as well as regulation of cellular responses to Type I interferon. The general opinion is that ADAR1 activity has a proviral impact and in case of viral absence it suppresses undesirable cellular immune responses (for example, mutations in adar gene cause Aicardi-Goutières syndrome with a childhood encephalitis and interferonopathy). The activity of ADAR2 was reported to be involved in regulation of the central nervous system, for example, in the form of excitatory stimuli (Fig. 1).

It was also reported that RNA editing events can play a crucial role in development of cancer. The activity of ADAR1 is likely to have oncogenic effect. The edited AZIN1 protein can be considered a potential therapeutic target. The edited form of COG3 protein can serve as a predictive marker and have an effect on cellular response in cancer therapy [15]. In case of CDC14B, PODXL, GABRA3 and IGFBP7 proteins, ADAR2 editing may probably have oncosupressing effects [4]. 


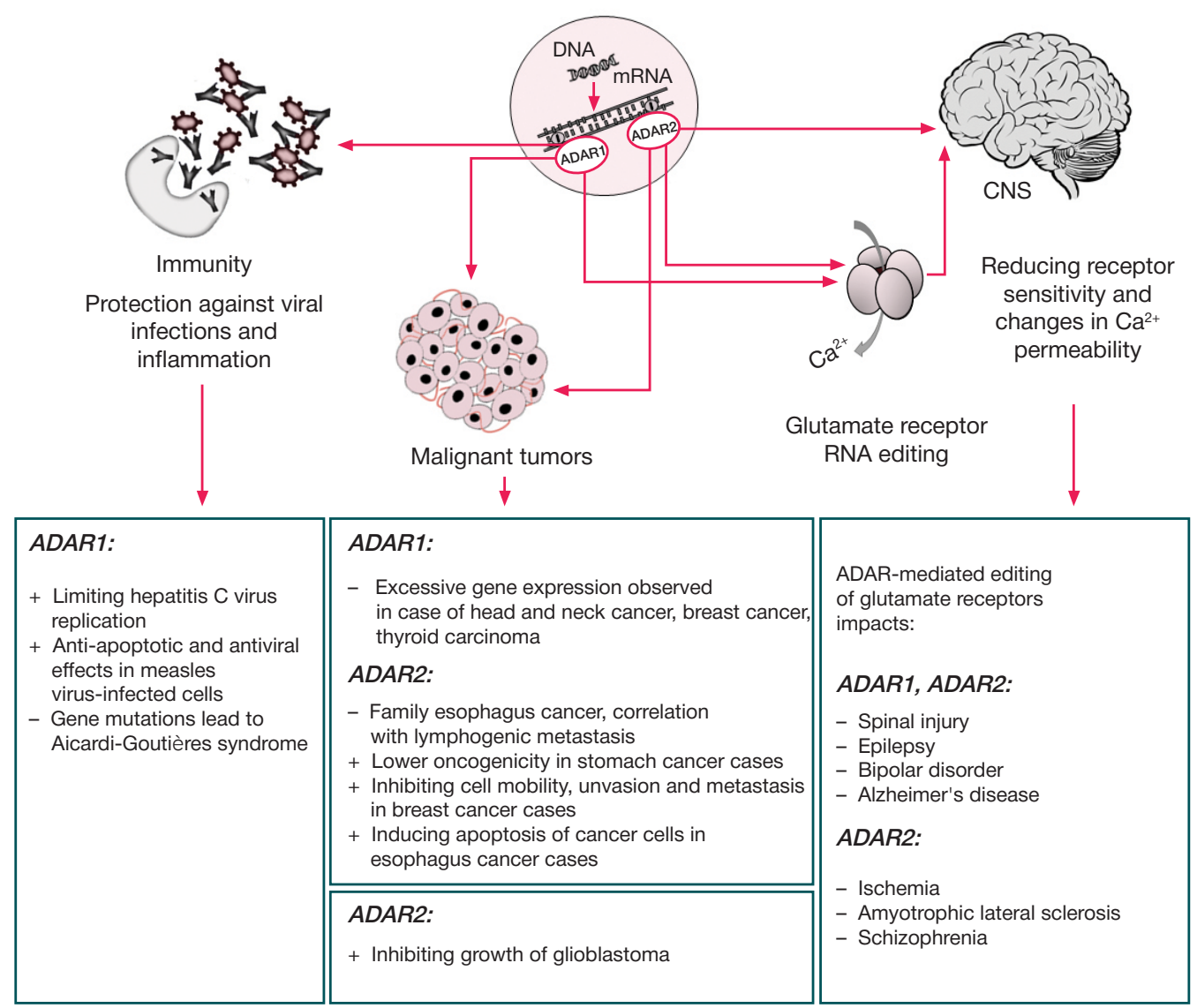

Fig. 1. ADAR effects associated with human diseases. Changes in ADAR1 activities are assiciated with immune protection against viral infections and inflammation and with certain types of cancer; RNA editing in glutamate receptors normally occurs in CNS. ADAR2 effects are associated with both positive and negative impacts on tumor progression while its deficiency may cause various CNS disorders

\section{CONCLUSIONS}

Based on the above-referenced examples, ADAR-mediated RNA editing is an evolutionarily ancient mechanism having various, yet understudied, functions in embryonic development of the central nervous system in particular. In pathological conditions such as neurodegenerative diseases and malignant tumors, levels of editing of many transcripts are changed. It is necessary to further investigate the mechanisms of cellular and histological effects of RNA editing. It is also important to distinguish significant editing events from the molecular noise and to find out whether it is possible to consider ADAR enzymes and related products as predictive biomarkers and molecular targets for therapeutic strategies.

\section{References}

1. Tan MH, Li Q, Shanmugam R, Piskol R, Kohler J, Young AN, et al. Dynamic landscape and regulation of RNA editing in mammals. Nature. 2017; (550): 249-54

2. Basilio C, Wahba AJ, Lengyel P, Speyer JF, Ochoa S. Synthetic polynucleotides and the amino acid code. $V$ Proc Natl Acad Sci USA. 1962; (48): 613-6.

3. Liscovitch-Brauer N, Alon S, Porath HT, Elstein B, Unger R, Ziv T, et al. Trade-off between Transcriptome Plasticity and Genome Evolution in Cephalopods. Cell. 2017; (169): 191-202.e11.

4. Gallo A, Vukic D, Michalík D, O'Connell MA, Keegan LP. ADAR RNA editing in human disease; more to it than meets the I. Hum Genet. 2017; (136): 1265-78.

5. Young PE, Kum Jew S, Buckland ME, Pamphlett R, Suter CM. Epigenetic differences between monozygotic twins discordant for amyotrophic lateral sclerosis (ALS) provide clues to disease pathogenesis. PLoS One. 2017; (12): e0182638.

6. Taylor DR, Puig M, Darnell MER, Mihalik K, Feinstone SM. New antiviral pathway that mediates hepatitis $C$ virus replicon interferon sensitivity through ADAR1. J Virol. 2005; (79): 6291-8.

7. Suspène R, Petit $\mathrm{V}$, Puyraimond-Zemmour D, Aynaud MM, Henry M, Guétard D, et al. Double-stranded RNA adenosine deaminase
ADAR-1-induced hypermutated genomes among inactivated seasonal influenza and live attenuated measles virus vaccines. J Virol. 2011; (85): 2458-62.

8. John L, Samuel CE. Induction of stress granules by interferon and down-regulation by the cellular RNA adenosine deaminase ADAR1. Virology. 2014; (454-455): 299-310.

9. Crow YJ. Aicardi-Goutières syndrome. Handb Clin Neurol. 2013; (113): 1629-35.

10. Tomczak K, Czerwińska P, Wiznerowicz M. The Cancer Genome Atlas (TCGA): an immeasurable source of knowledge. Contemp Oncol (Poznan, Poland). 2015; (19): A68-77.

11. Peng X, Xu X, Wang Y, Hawke DH, Yu S, Han L, et al. A-to-I RNA Editing Contributes to Proteomic Diversity in Cancer. Cancer Cell. 2018; (33): 817-828.e7.

12. Galeano F, Rossetti C, Tomaselli S, Cifaldi L, Lezzerini M, Pezzullo M, et al. ADAR2-editing activity inhibits glioblastoma growth through the modulation of the CDC14B/Skp2/p21/p27 axis. Oncogene. 2013; (32): 998-1009.

13. Chen L, Li Y, Lin CH, Chan THM, Chow RKK, Song Y, et al. Recoding RNA editing of AZIN1 predisposes to hepatocellular carcinoma. Nat Med. 2013; (19): 209-16. 
14. Han L, Diao L, Yu S, Xu X, Li J, Zhang R, et al. The Genomic Landscape and Clinical Relevance of A-to-I RNA Editing in Human Cancers. Cancer Cell. 2015; (28): 515-28.

\section{Литература}

1. Tan MH, Li Q, Shanmugam R, Piskol R, Kohler J, Young AN, et al. Dynamic landscape and regulation of RNA editing in mammals. Nature. 2017; (550): 249-54.

2. Basilio C, Wahba AJ, Lengyel P, Speyer JF, Ochoa S. Synthetic polynucleotides and the amino acid code. $V$ Proc Natl Acad Sci USA. 1962; (48): 613-6.

3. Liscovitch-Brauer N, Alon S, Porath HT, Elstein B, Unger R, Ziv T, et al. Trade-off between Transcriptome Plasticity and Genome Evolution in Cephalopods. Cell. 2017; (169): 191-202.e11.

4. Gallo A, Vukic D, Michalík D, O'Connell MA, Keegan LP. ADAR RNA editing in human disease; more to it than meets the I. Hum Genet. 2017; (136): 1265-78.

5. Young PE, Kum Jew S, Buckland ME, Pamphlett R, Suter CM. Epigenetic differences between monozygotic twins discordant for amyotrophic lateral sclerosis (ALS) provide clues to disease pathogenesis. PLoS One. 2017; (12): e0182638.

6. Taylor DR, Puig M, Darnell MER, Mihalik K, Feinstone SM. New antiviral pathway that mediates hepatitis $\mathrm{C}$ virus replicon interferon sensitivity through ADAR1. J Virol. 2005; (79): 6291-8.

7. Suspène R, Petit V, Puyraimond-Zemmour D, Aynaud MM, Henry M, Guétard D, et al. Double-stranded RNA adenosine deaminase ADAR-1-induced hypermutated genomes among inactivated seasonal influenza and live attenuated measles virus vaccines. J Virol. 2011; (85): 2458-62.
15. $\mathrm{Xu} X$, Wang $\mathrm{Y}$, Liang $\mathrm{H}$. The role of A-to-I RNA editing in cancer development. Curr Opin Genet Dev. 2018; (48): 51-6.
8. John L, Samuel CE. Induction of stress granules by interferon and down-regulation by the cellular RNA adenosine deaminase ADAR1. Virology. 2014; (454-455): 299-310.

9. Crow YJ. Aicardi-Goutières syndrome. Handb Clin Neurol. 2013; (113): 1629-35.

10. Tomczak K, Czerwińska P, Wiznerowicz M. The Cancer Genome Atlas (TCGA): an immeasurable source of knowledge. Contemp Oncol (Poznan, Poland). 2015; (19): A68-77.

11. Peng $X, X u X$, Wang $Y$, Hawke DH, Yu S, Han L, et al. A-to-I RNA Editing Contributes to Proteomic Diversity in Cancer. Cancer Cell. 2018; (33): 817-828.e7.

12. Galeano F, Rossetti C, Tomaselli S, Cifaldi L, Lezzerini M, Pezzullo M, et al. ADAR2-editing activity inhibits glioblastoma growth through the modulation of the CDC14B/Skp2/p21/p27 axis. Oncogene. 2013; (32): 998-1009.

13. Chen L, Li Y, Lin CH, Chan THM, Chow RKK, Song $Y$, et al. Recoding RNA editing of AZIN1 predisposes to hepatocellular carcinoma. Nat Med. 2013; (19): 209-16.

14. Han L, Diao L, Yu S, Xu X, Li J, Zhang R, et al. The Genomic Landscape and Clinical Relevance of A-to-I RNA Editing in Human Cancers. Cancer Cell. 2015; (28): 515-28.

15. $\mathrm{Xu} X$, Wang $\mathrm{Y}$, Liang $\mathrm{H}$. The role of A-to-I RNA editing in cancer development. Curr Opin Genet Dev. 2018; (48): 51-6. 